\title{
Kontribusi Sektor Pariwisata Terhadap Ekonomi Wilayah di Provinsi Jawa Timur
}

\author{
Riswandha Risang Aji, Retno Widodo Dwi Pramono, dan Dwita Hadi Rahmi \\ Magister Perencanaan Wilayah dan Kota, Universitas Gadjah Mada,
} rra@outlook.co.id

INFO ARTIKEL
Riwayat Artikel:
Diterima: 8-7-2018
Disetujui: 4-8-2018

\section{Kata Kunci:}

Pariwisata

Forward linkage

Backward linkage

Analisis jalur

Perkembangan wilayah

\begin{abstract}
ABSTRAK
Abstrak: Penelitian ini bertujuan untuk melihat kontribusi sektor pariwisata terhadap ekomomi wilayah di provinsi Jawa Timur. Metode yang dilakukan dala penelitian ini adalah deduktif kuantitatif. Temuan dari penelitian ini diperoleh bahwa Sektor Informasi dan Komunikasi meningkatkan ekonomi dengan cara melalui forward linkage memenuhi demand wisatawan terhadap informasi mengenai objek pariwisata sehingga wisatawan membelanjakan uangnya melalui sektor ini. Melalui backward linkage sektor Informasi dan Komunikasi memberikan supply informasi mengenai objek pariwisata kepada sektor-sektor yang menjadi input bagi sektor pariwisata.
\end{abstract}

\begin{abstract}
This study aims to see the contribution of the tourism sector to the regional economy in the East Java province. The method used in this research is quantitative deductive. The findings of this study show that the Information and Communication Sector improves the economy by way of forward linkage to meet tourist demand for information about tourism objects so that tourists spend their money through this sector. Through the backward linkage the Information and Communication sector provides supply of information about tourism objects to sectors that are input for the tourism sector.
\end{abstract}

\section{A. LATAR BELAKANG}

Perkembangan wilayah dikenali dari beberapa aspek seperti aspek ekonomi, sosial, lingkungan, fisik, dan kelembagaan. Aspek ekonomi menjadi bagian yang paling penting dalam perkembangan wilayah karena basis ekonomi sebuah wilayah menentukan perkembangan wilayah tersebut [1]. Dalam ekonomi wilayah dikenal istilah basis ekonomi. Sektor yang menjadi basis ekonomi salah satunya adalah pariwisata. Basis ekonomi penting bagi perkembangan wilayah melalui produksi sebuah wilayah baik untuk konsumsi wilayah itu sendiri maupun yang berorientasi ekspor dan menjadi sumbu awal dalam multiplier effect bagi sektor-sektor lainnya. Kaitannya dengan penelitian ini basis ekonomi yang dibahas adalah pariwisata yang saat ini banyak menjadi tumpuan bagi beberapa wilayah. Periwisata mempunyai multiplier effect yang bisa berdampak pada perkembangan sebuah wilayah [2]. Pariwisata dipercaya dapat menyediakan lapangan pekerjaan baik secara langsung maupun tidak langsung.

Pengembangan ekonomi sebuah wilayah bisa dilakukan melalui pengembangan sektor-sektor yang memiliki potensi sebagai kegiatan produksi. Pengembangan pariwisata sebagai kegiatan produksi bisa dilakukan dengan produksi jangka panjang, yakni menambah faktor produksi seperti skala pelayanan dan jumlah objek wisata yang dikelola sehingga dalam jangka panjang akan memberikan keuntungan terhadap wilayah tersebut [3].

Kegiatan pariwisata dalam lingkup ekonomi wilayah merupakan salah satu sektor produksi yang menyumbang pendapatan wilayah baik secara langsung maupun tidak langsung. Namun demikian pariwisata dalam berbagai literatur dan penelitian tidak pernah ditempatkan sebagai satu sektor khusus dalam perkembangan wilayah, sehingga penelitian ini dilakukan untuk melihat peran sektor pariwisata dalam perkembangan wilayah. Salah satu cara untuk mengukur sebuah sektor dalam perkembangan wilayah adalah analisis Input Output. Input output sendiri terdiri dari beberapa sektor yang tercatat dalam tabel input output. Sektor-sektor tersebut dipahami sebagai penyusun ekonomi wilayah. Sehingga melalui analisis input output akan diketahui seberapa besar peran pariwisata terhadap ekonomi wilayah.

Sektor pariwisata belum berdiri sendiri sebagai sebuah sektor di PDRB. Saputra [14] menjelaskan sektor pariwisata dibentuk melalui agregasi sektor dari tabel Input-Output sehingga menghasilkan 5 sektor pembentuk sektor pariwisata, yakni Angkutan, Pergudangan, Jasa Penunjang Angkutan, Pos dan Kurir; 
Penyediaan Akomodasi dan Penyediaan Makanan dan Minuman; Informasi dan Komunikasi; Jasa Perusahaan; dan Jasa Kesehatan dan Kegiatan Sosial.

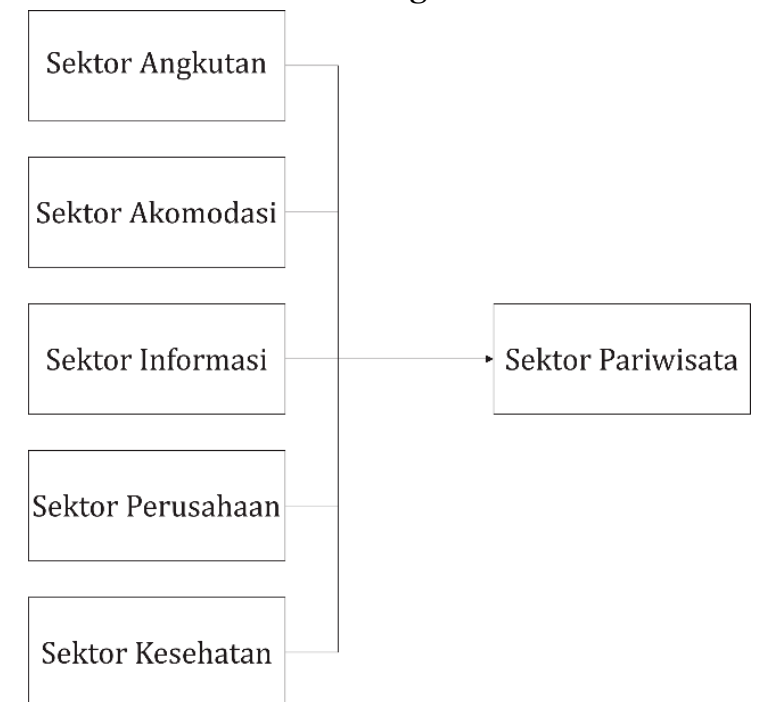

Gambar 1. Sektor-Sektor Pembentuk Sektor Pariwisata

Pariwisata dalam kasus tertentu juga memiliki beberapa kondisi yang menyebabkan pariwisata memiliki sektor lain yang membentuknya. Kondisi tersebut salah satunya adalah citra sebuah kawasan, contohnya kawasan pendidikan. Berkaitan dengan hal tersebut pariwisata memiliki multiplier effect yang berpengaruh terhadap industri-industri lain yang mendukung pariwisata itu sendiri baik secara langsung maupun tidak langsung [4]. Pendidikan khususnya pendidikan tinggi merupakan salah satu hal yang mendukung pariwisata, sehingga industrialisasi pendidikan tinggi cepat atau lambat akan terjadi. Pendidikan sendiri merupakan salah satu komponen penawaran pariwisata yang mampu menarik orang baik untuk belajar dan tinggal di kawasan pendidikan maupun hanya untuk mengunjungi kawasan pendidikan tersebut [5]. Multiplier effect pariwisata dan pendidikan merupakan hal yang tidak dapat dipisahkan dari wisatawan. Pendidikan sebagai bagian dari penawaran pariwisata maupun sebagai hasil dari multiplier effect pariwisata memiliki kedudukan yang mampu menarik wisatawan, sehingga jasa pendidikan merupakan salah satu sektor yang membentuk sektor pariwisata.

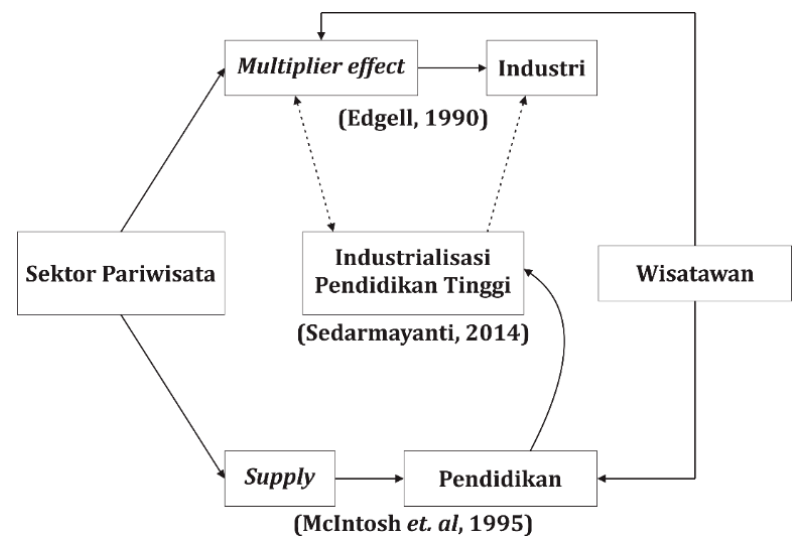

Gambar 2. Sektor Pendidikan sebagai Sektor

Pariwisata

\section{B. METODE PENELITIAN}

Metode yang dilakukan dala penelitian ini adalah deduktif kuantitatif. Metode kuantitatif merupakan metode yang digunakan untuk meneliti keadaan tertentu dengan mengumpulkan data menggunakan instrumen penelitian kemudian dianalisis secara statistik yang bertujuan untuk menguji hipotesis [6 dan 7].

Lokasi penelitian ini adalah provinsi Jawa Timur. Penentuan lokasi ini menggunakan stusi kasus, yakni peneliti menentukan sendiri lokasi penelitian dengan pertimbangan kasus atau keunikan tertentu yang dimiliki oleh sebuah wilayah jika dibandingkan dengan wilayah lain [8].

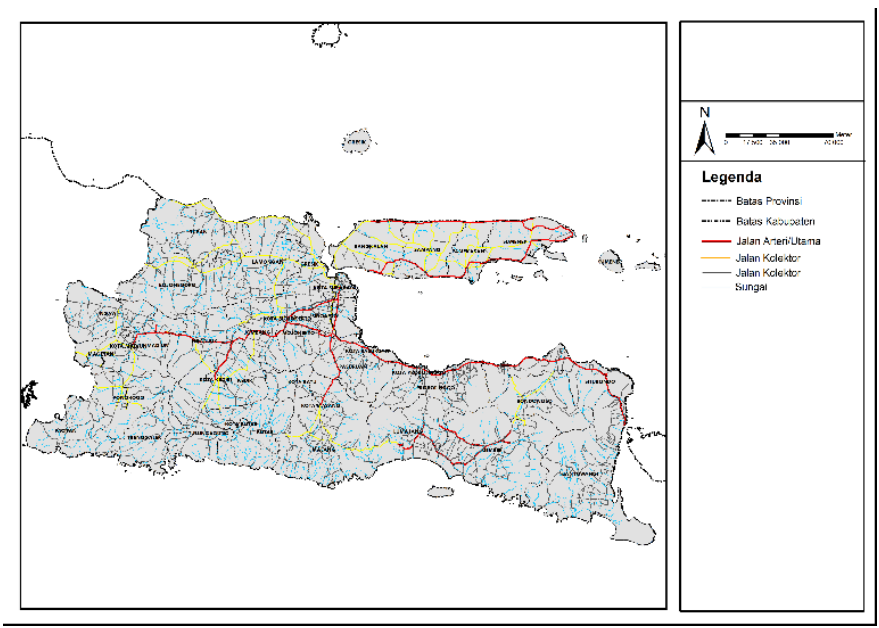

Gambar 3. Peta Lokasi Penelitian Provinsi Jawa Timur

\section{Analisis Kontribusi}

Metode analisis data untuk mengukur kontribusi kegiatan pariwisata terhadap ekonomi wilayah adalah dengan perhitungan analisis kontribusi. Analisi kontribusi digunakan untuk melihat persentase sebuah sektor dalam membentuk PDRB [9].

$$
K=\frac{S_{i}}{\text { Total } P D R B} \times 100 \%
$$

Keterangan:

$K=$ Persentase kontribusi sebuah sektor

$S_{i}=$ Sektor yang diukur persentasenya

Unit amatan yang digunakan pada analisis kontribusi adalah PDRB provinsi. Hasil dari analisis ini berupa kontribusi sektor pariwisata terhadap ekonomi wilayah dalam lingkup provinsi.

\section{Analisis Input-Output}

Metode analisis data untuk menjelaskan cara kegiatan pariwisata berkontribusi terhadap ekonomi wilayah di provinsi Jawa Timur adalah analisis input output. Analisis Input-Output merupakan penggambaran perekonomian suatu wilayah menggunakan prinsip General Equilibrium pada periode tertentu melalui aliran inter-industri [10]. Analisis input output yang digunakan adalah analisis linkage. Analisis linkage digunakan untuk melihat keterkaitan sektor tertentu dengan sektor-sektor lain yang menyusun perekonomian sebuah wilayah secara langsung dan tidak langsung baik forward linkage maupun backward linkage [11]. 
Analisis forward linkage digunakan untuk mengukur akibat dari sektor tertentu terhadap sektor-sektor lain yang menyediakan output bagi sektor tersebut per unit kenaikan permintaan total. Analisis forward linkage dapat dihitung menggunkan rumus:

$$
F L T L_{i}=\sum_{j=1}^{n} C_{i j}
$$

Keterangan:

\section{$F L T L_{i}=$ Forward Linkage}

$C_{i j}=$ Unsur Matriks Invers Leontief

Unsur Matriks Invers Leontief didapatkan dari output sektor-sektor pembentuk sektor pariwisata yakni Angkutan, Pergudangan, Jasa Penunjang Angkutan, Pos dan Kurir; Penyediaan Akomodasi dan Penyediaan Makanan dan Minuman; Informasi dan Komunikasi; Jasa Perusahaan; Jasa Kesehatan dan Kegiatan Sosial; dan Jasa Pendidikan. Forward linkage yang dihasilkan berarti pengaruh output masing-masing sektor terhadap output keseluruhan ekonomi wilayah. Hasil analisis forward linkage digunakan untuk melihat cara sektor pariwisata memberikan pengaruhnya terhadap ekonomi wilayah melalui keterkaitan ke depan sektor pariwisata dengan sektor-sektor lain.

Analisis backward linkage digunakan untuk mengukur akibat dari sektor tertentu terhadap sektorsektor lain yang menyediakan input bagi sektor tersebut per unit kenaikan permintaan total. Analisis backward linkage dapat dihitung menggunkan rumus:

$$
B L T L_{i}=\sum_{j=1}^{n} C_{i j}
$$

Keterangan:

\section{$B L T L_{i}=$ Backward Linkage}

$C_{i j}=$ Unsur Matriks Invers Leontief

Unsur Matriks Invers Leontief didapatkan dari input sektor-sektor pembentuk sektor pariwisata yakni Angkutan, Pergudangan, Jasa Penunjang Angkutan, Pos dan Kurir; Penyediaan Akomodasi dan Penyediaan Makanan dan Minuman; Informasi dan Komunikasi; Jasa Perusahaan; Jasa Kesehatan dan Kegiatan Sosial; dan Jasa Pendidikan. Backward linkage yang dihasilkan berarti pengaruh input masing-masing sektor terhadap input keseluruhan sektor ekonomi wilayah terhadap sektor pariwisata. Hasil analisis backward linkage digunakan untuk melihat cara sektor pariwisata memberikan pengaruhnya terhadap ekonomi wilayah melalui keterkaitan ke belakang sektor pariwisata dengan sektor-sektor lain.

\section{Analisis Jalur}

Metode analisis data untuk menjelaskan cara kegiatan pariwisata pantai berkontribusi terhadap ekonomi wilayah di provinsi Jawa Timur selain analisis input output adalah analisis jalur. Analisis jalur merupakan metode yang digunakan untuk mengukur kekuatan dari pengaruh antar variabel dengan menggunakan data kuantitatif yang saling berhubungan
[12]. Model analisis jalur yang digunakan dalam penelitian ini adalah model regresi berganda yakni menggunakan dua atau lebih variabel exogenus atau variabel bebas $\left(\mathrm{X}_{1}, \mathrm{X}_{2}, \ldots \mathrm{X}_{\mathrm{n}}\right)$ dan satu variabel endogenus atau variabel terikat $(\mathrm{Y})$ [13].

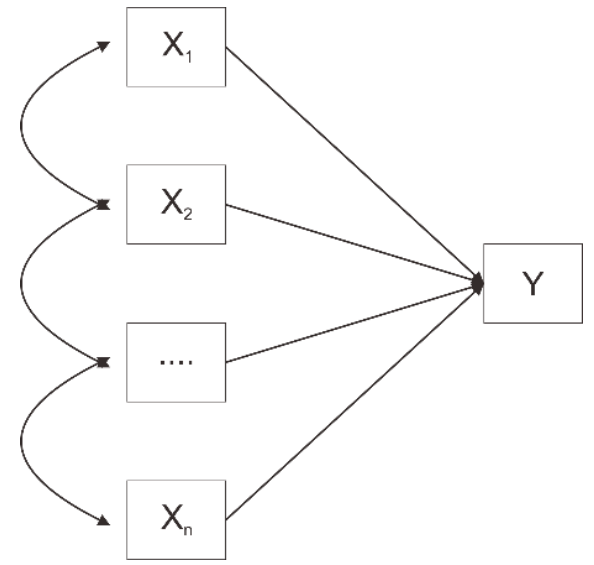

Gambar 4. Model Regresi Berganda

Regresi berganda menjelaskan variabel terikat dipengaruhi oleh dua atau lebih variabel bebas, fungsi dari regresi berganda adalah sebagai berikut

$$
Y=f\left(X_{1}, X_{2}, \ldots . X_{n}\right)
$$

Keterangan:

$Y=$ Variabel terikat (dependent)

$X_{1}, X_{2}, \ldots, X_{n}=$ Variabel bebas (independent)

Variabel terikat adalah output sektor-sektor dalam PDRB selain sektor-sektor pembentuk sektor pariwisata untuk melihat forward linkage dan input sektor-sektor dalam PDRB selain sektor-sektor pembentuk sektor pariwisata untuk melihat backward linkage. Variabel bebas adalah output sektor-sektor pembentuk sektor pariwisata untuk melihat forward linkage dan input sektor-sektor pembentuk sektor pariwisata untuk melihat backward linkage.

\section{HASIL DAN PEMBAHASAN}

\section{Kontribusi Sektor Pariwisata terhadap Ekonomi Wilayah}

Kontribusi sektor pariwisata di provinsi Jawa Timur terhadap ekonomi wilayah di masing-masing provinsi dilihat melalui PDRB masing-masing melalui sektorsektor pembentuknya seperti Angkutan, Pergudangan, Jasa Penunjang Angkutan, Pos dan Kurir; Penyediaan Akomodasi dan Penyediaan Makanan dan Minuman; Informasi dan Komunikasi; Jasa Perusahaan; Jasa Pendidikan; dan Jasa Kesehatan dan Kegiatan Sosial.

Sektor pariwisata berkontribusi terhadap PDRB provinsi Jawa Timur. Kontribusi sektor pariwisata dalam PDRB di provinsi Jawa Timur pada tahun 2013 adalah 17,30\%, pada tahun 2014 adalah 17,14\%, pada tahun 2015 adalah 17,46\%, dan pada tahun 2016 adalah 17,76\% 


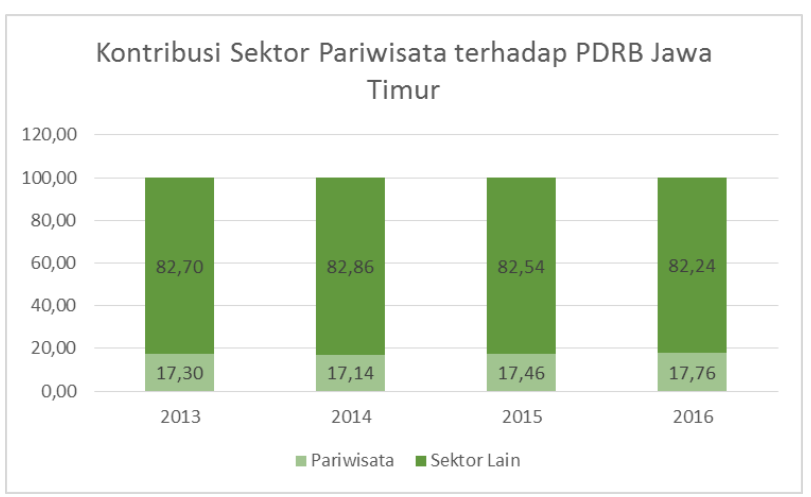

Gambar 5. Kontribusi Pariwisata Jawa Timur

Kontribusi sektor pariwisata terhadap PDRB provinsi Jawa Timur sekitar $17 \%$ setiap tahunnya. Kecenderungan kontribusi pariwisata di provinsi Jawa Timur mengalami kenaikan sehingga berpotensi menjadi basis ekonomi.

\section{Cara Sektor Pariwisata Berkontribusi terhadap Ekonomi Wilayah}

Kegiatan pariwisata pantai dilihat perannya melalui sektor-sektor yang membentuk sektor pariwisata. Sektorsektor tersebut dianalisis menggunakan analisis forward linkage, backward linkage, dan analisis jalur untuk dilihat kontribusinya.

Sektor pariwisata terbentuk melalui enam sektor pembentuknya yakni Angkutan, Pergudangan, Jasa Penunjang Angkutan, Pos dan Kurir; Penyediaan Akomodasi dan Penyediaan Makanan dan Minuman; Informasi dan Komunikasi; Jasa Perusahaan; Jasa Pendidikan; dan Jasa Kesehatan dan Kegiatan Sosial. Sektor-sektor tersebut dianalisis untuk menunjukkan sektor utama pembentuk pariwisata. Sektor utama pembentuk sektor pariwisata digunakan untuk mengukur kontribusi kegiatan pariwisata pantai dalam perkembangan wilayah. Sektor utama pembentuk sektor pariwisata dapat ditemukan melalui analisis input output yang terdiri dari forward linkage dan backward linkage.

\section{a. Forward linkage}

Forward Linkage Pariwisata Provinsi Jawa Timur yang terbesar adalah sektor Informasi dan Komunikasi yakni 1,41. Hal ini berarti setiap peningkatan output sektor Informasi dan Komunikasi sebesar 1 juta maka akan meningkatkan output permintaan total sektor pariwisata sebesar 1,41 juta.

Forward linkage terbesar kedua provinsi Jawa Timur adalah sektor Angkutan, Pergudangan, Jasa Penunjang Angkutan, Pos dan Kurir yakni 1,28. Hal ini berarti setiap peningkatan output sektor Angkutan, Pergudangan, Jasa Penunjang Angkutan, Pos dan Kurir sebesar 1 juta maka akan meningkatkan output permintaan total sektor pariwisata sebesar 1,28 juta.

\section{Tabel 1}

Analisis forward linkage provinsi jawa timur

\begin{tabular}{clc}
\hline No & \multicolumn{1}{c}{ Sektor } & FL \\
\hline 1 & Informasi dan Komunikasi & 1,41 \\
2 & Angkutan, Pergudangan, & 1,28 \\
& Jasa Penunjang Angkutan, & \\
& Pos dan Kurir
\end{tabular}

\begin{tabular}{clc}
\hline No & \multicolumn{1}{c}{ Sektor } & FL \\
\hline 3 & $\begin{array}{l}\text { Penyediaan Akomodasi } \\
\text { dan Penyediaan Makanan }\end{array}$ & 1,12 \\
& dan Minuman & \\
4 & Jasa Perusahaan & 1,06 \\
5 & Jasa Kesehatan dan & 1,06 \\
& Kegiatan Sosial & \\
6 & Jasa Pendidikan & 1,00 \\
\hline \multicolumn{2}{l}{ Sumber: Hasil Analisis, 2018 }
\end{tabular}

Sektor pariwisata melalui sektor Informasi dan Komunikasi mampu meningkatkan ekonomi wilayah melalui forward linkage dengan cara menyediakan pengetahuan mengenai keberadaan objek pariwisata sehingga mengundang wisatawan untuk mendatangi wilayah tersebut. Pengetahuan mengenai objek pariwisata tersebut bisa berupa iklan objek pariwisata itu sendiri, informasi mengenai agen perjalanan, maupun promosi mengenai keunikan objek pariwisata itu sendiri yang belum tentu ada di tempat asal wisatawan. Wisatawan yang mengunjungi objek pariwisata dalam suatu wilayah akan memberikan pendapatan terhadap ekonomi wilayah baik secara langsung melalui penerimaan retribusi maupun secara tidak langsung melalui belanja wisatawan.

Selain itu sektor Informasi dan Komunikasi menjadi sektor yang penting di kedua provinsi karena sekarang merupakan era digital yang membuat arus informasi menjadi berpengaruh terhadap berbagai hal termasuk pariwisata. Informasi yang berpengaruh terhadap pariwisata adalah informasi mengenai komponenkomponen dari pariwisata. Wisatawan pada era digital cenderung mencari informasi mengenai tempat yang menjadi tujuan mereka terlebih dahulu sebelum mengunjungi tempat tersebut. Provinsi Jawa Timur menyediakan informasi untuk dimanfaatkan wisatawan yang akan berkunjung melalui berbagai media baik digital maupun cetak.

b. Backward linkage

Analisis yang dilakukan setelah forward linkage adalah analisis backward linkage. Backward Linkage Pariwisata Provinsi Jawa Timur yang terbesar adalah sektor Informasi dan Komunikasi yakni 1,25. Hal ini berarti setiap peningkatan input sektor Informasi dan Komunikasi sebesar 1 juta maka akan meningkatkan input permintaan total sektor pariwisata sebesar 1,25 juta

Backward linkage terbesar kedua provinsi Jawa Timur adalah sektor Angkutan, Pergudangan, Jasa Penunjang Angkutan, Pos dan Kurir yakni 1,23. Hal ini berarti setiap peningkatan input sektor Angkutan, Pergudangan, Jasa Penunjang Angkutan, Pos dan Kurir sebesar 1 juta maka akan meningkatkan input permintaan total sektor pariwisata sebesar 1,23 juta. 
Tabel 2

Analisis backward linkage provinsi jawa timur

\begin{tabular}{clc}
\hline No & \multicolumn{1}{c}{ Sektor } & FL \\
\hline 1 & Informasi dan Komunikasi & 1,25 \\
2 & Angkutan, Pergudangan, & 1,23 \\
& Jasa Penunjang Angkutan, & \\
& Pos dan Kurir & \\
3 & Jasa Pendidikan & 1,19 \\
4 & Jasa Perusahaan & 1,15 \\
5 & Jasa Kesehatan dan & 1,10 \\
& Kegiatan Sosial & \\
6 & Penyediaan Akomodasi & 1,01 \\
& dan Penyediaan Makanan & \\
& dan Minuman & \\
\hline
\end{tabular}

Sumber: Hasil Analisis, 2018

Sektor Informasi dan Komunikasi menjadi sektor penting karena merupakan sektor yang menarik wisatawan di provinsi Jawa Timur. Sektor Informasi dan Komunikasi melalui backward linkage memberikan pengtahuan mengenai wisatawan kepada sektor-sektor yang memberikan input ke sektor pariwisata. Selain itu sektor Informasi dan Komunikasi memberikan input terhadap ekonomi wilayah dengan cara pendapatan langsung dari pajak iklan dan pendapatan dari media cetak maupun elektronik.

Sektor lain yang berpengaruh terhadap pariwisata di provinsi Jawa Timur adalah sektor Angkutan, Pergudangan, Jasa Penunjang Angkutan, Pos dan Kurir. Input dari sektor Angkutan, Pergudangan, Jasa Penunjang Angkutan, Pos dan Kurir berpengaruh karena digunakan untuk menunjang mobilitas wisatawan di provinsi Jawa Timur.

\section{Pola Kontribusi Sektor Pariwisata Provinsi Jawa Timur}

Keterkaitan antar sektor dapat diungkap melalui analisis jalur yang menghasilkan pola. Pola keterkaitan ini digunakan untuk menjawab tujuan penelitian mengukur kontribusi kegiatan pariwisata pantai dalam perkembangan wilayah. Analisis Jalur dilakukan dengan melihat input terbesar dan output terbesar dari masingmasing sektor pembentuk sektor pariwisata di Tabel Input Output hasil agregasi 17 sektor dan melihat keterkaitan antar sektor-sektor pembentuk sektor pariwisata.

Sektor pariwisata berkontribusi melalui keterkaitan terhadap sektor lain. Keterkaitan yang bisa disebut berpengaruh besar adalah keterkaitan yang memiliki nilai sig dibawah 0,05 dan linkage yang bisa disebut berpengaruh kecil adalah keterkaitan yang memiliki nilai antara 0,05 hingga 0,10

Hasil analisis jalur di provinsi Jawa Timur menunjukkan hasil forward linkage sektor Penyediaan Akomodasi dan Penyediaan Makanan dan Minuman sebagai sektor yang memiliki pengaruh tertinggi yakni berpengaruh terhadap sektor pertanian. Hasil tersebut diikuti sektor Informasi dan Komunikasi yang mempengaruhi sektor pertanian dan sektor real estate. Sedangkan hasil backward linkage menunjukkan sektor Jasa Kesehatan dan Kegiatan Sosial sebagai sektor yang paling berpengaruh terhadap ekonomi wilayah. Sektor Jasa Kesehatan dan Kegiatan Sosial menjadi stimulan bagi sektor perdagangan untuk memberikan input terhadap sektor pariwisata. Hasil tersebut diikuti sektor Jasa Perusahaan yang menjadi stimulan sektor listrik dan sektor Informasi dan Komunikasi yang menjadi stimulan sektor perdagangan untuk memberikan input bagi sektor pariwisata.

Analisis Jalur menghasilkan path diagram yang menggambarkan jalur-jalur sektor-sektor pembentuk sektor pariwisata dalam mempengaruhi sektor-sektor lain. Path diagram memiliki dua jalur yakni arah ke kanan yang berarti forward linkage dan arah ke kiri yang berarti backward linkage.

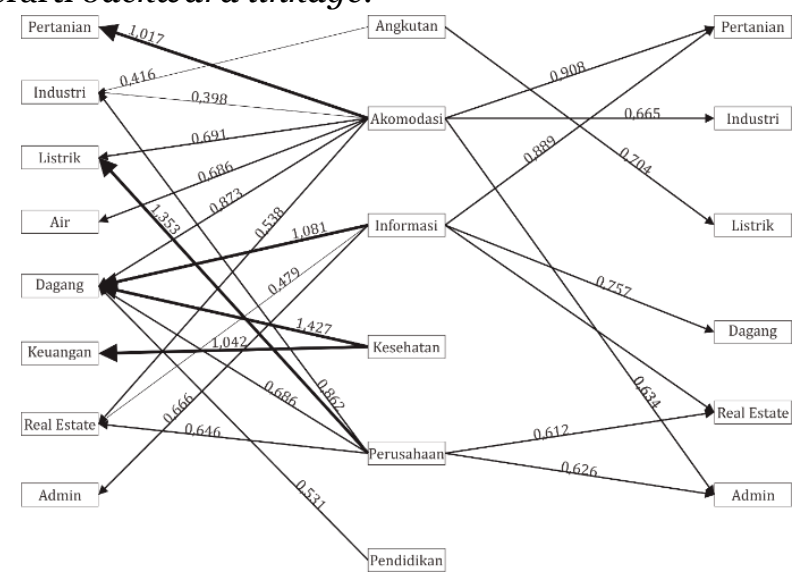

Gambar 6. Path Diagram Provinsi Jawa Timur

Arah panah ke kanan berarti forward linkage sedangkan arah panah ke kiri berarti backward linkage. Nilai 0,908 pada panah ke kanan dari akomodasi menuju pertanian berarti setiap kenaikan output sebesar 1 juta pada akomodasi berarti kenaikan input sebesar 0,908 juta pada pertanian. Sedangkan nilai 1,427 pada panah ke kiri dari kesehatan menuju dagang berarti setiap kenaikan input sebesar 1 juta pada kesehatan akan menstimulan kenaikan sebesar 1,427 juta pada output dagang kepada kesehatan.

Dari diagram tersebut bisa dilihat ada sektor pembentuk pariwisata yang tidak terlalu berperan dalam ekonomi wilayah di Jawa Timur. Sektor pendidikan di Jawa Timur hanya memiliki satu keterkaitan yakni backward linkage terhadap sektor perdagangan tanpa memiliki forward linkage. Hal ini menunjukkan bahwa industrialisasi pendidikan yang dikemukakan Sedarmayanti (2014) belum mampu menjadikan sektor pendidikan menjadi sektor pariwisata yang berperan besar di provinsi Jawa Timur. Hal ini bisa jadi disebabkan oleh luasnya wilayah provinsi Jawa Timur sehingga sektor pendidikan hanya berperan di kota-kota besar yang menjadi pusat populasi di provinsi Jawa Timur seperti kota Surabaya dan kota Malang di mana kedua kota tersebut menjadi pusat pendidikan di provinsi Jawa Timur. Sedangkan untuk kabupaten-kabupaten yang 
bukan merupakan pusat populasi, sektor pendidikan menjadi tidak terlalu berperan dalam ekonomi wilayah, namun sektor-sektor pembentuk pariwisata lain seperti angkutan, akomodasi, informasi, dan perusahaan menjadi lebih berperan dalam ekonomi wilayah.

Sektor lain yang juga tidak memiliki forward linkage adalah sektor kesehatan. Namun sektor kesehatan memiliki backward linkage tertinggi di provinsi Jawa Timur. Sektor kesehatan memberikan backward linkage yang cukup besar terhadap sektor perdagangan dan sektor keuangan, artinya sektor kesehatan memberikan investasi yang cukup besar namun tidak memberikan output yang besar untuk ekonomi wilayah di provinsi Jawa Timur. Sehingga peran sektor kesehatan maupun sektor pendidikan dalam membentuk pariwisata di provinsi Jawa Timur belum signifikan.

Sektor pembentuk pariwisata yang berpotensi berperan besar di provinsi Jawa Timur adalah sektor angkutan. Walaupun hanya memiliki masing-masing satu forward linkage dan backward linkage, sektor angkutan memiliki potensi berkembang karena wilayah provinsi Jawa Timur yang luas. Jika dikembangkan lebih lanjut melalui sektor-sektor yang sudah lebih berkembang seperti sektor informasi dengan cara mempromosikan angkutan dalam promosi pariwisata maka sektor angkutan akan bisa dimaksimalkan potensinya. Luasnya wilayah provinsi Jawa Timur sendiri sudah menjadi lahan yang tepat untuk pengembangan sektor angkutan.

\section{SIMPULAN DAN SARAN}

Sektor Informasi dan Komunikasi meningkatkan ekonomi dengan cara melalui forward linkage memenuhi demand wisatawan terhadap informasi mengenai objek pariwisata sehingga wisatawan membelanjakan uangnya melalui sektor ini. Melalui backward linkage sektor Informasi dan Komunikasi memberikan supply informasi mengenai objek pariwisata kepada sektor-sektor yang menjadi input bagi sektor pariwisata.

Saran untuk peneliti selanjutnya adalah untuk meneliti kebijakan-kebijakan yang dilakukan oleh pemerintah dalam mengembangkan ekonomi wilayah melalui sektor pariwisata.

\section{UCAPAN TERIMA KASIH}

Tim penulis mengucapkan terima kasih kepada MPKD UGM dan teman-teman yang mendukung penelitian ini.

\section{DAFTAR RUJUKAN}

[1] Nourse, Hugh O, Regional Economics: A Study in the Economic Structure, Stability, and Growth of Regions. McGraw-Hill Book Company, New York, 1968.

[2] Kotler, Philip., Haider, Donald H., dan Rein, Irving, Marketing Places: Attracting Investment, Industry, and Tourism to Cities, States, and Nations. The Free Press A Division of Maximilian, Inc. New York, 1993.
[3] Nopirin, Pengantar Ilmu Ekonomi Makro \& Mikro. BPFE UGM, Yogyakarta, 2000.

[4] Edgell, David L, International Tourism Policy. Van Nostrand Reinhold, New York, 1990.

[5] McIntosh, Robert W., Goeldner, Charles R., dan Ritchie, J. R. Brent, Tourism Principles, Practices, Philosophies. John Wiley \& Sons, Inc. New York, 1995.

[6] Kountur, Ronny, Metode Penelitian untuk Penulisan Skripsi dan Tesis. Penerbit PPM, Jakarta, 2004.

[7] Sugiyono, Metode Penelitian Kombinasi (Mixed Methods). CV. Alfabeta, Bandung, 2015.

[8] Yunus, Hadi Sabari, Metodologi Penelitian Wilayah Kontemporer. Pustaka Pelajar, Yogyakarta, 2010.

[9] Jhingan, M. L, Ekonomi Pembangunan dan Perencanaan. PT. Raja Grafindo Persada, Jakarta, 2002.

[10]Utama, I Gusti B. R., dan Mahadewi, Ni Made E, Metodologi Penelitian Pariwisata dan Perhotelan. Penerbit Andi, Yogyakarta, 2012.

[11] Budiharsono, Sugeng, Teknik Analisis Pembangunan Wilayah Pesisir dan Lautan. PT. Pradnya Paramita, Jakarta, 2001.

[12]Sandjojo, Nidjo, Metode Analisis Jalur (Path Analysis) dan Aplikasinya. Pustaka Sinar Harapan, Jakarta, 2011.

[13]Pardede, Ratlan, dan Manurung, Renhard, Analisis Jalur (Path Analysis) Teori dan Aplikasinya dalam Riset Bisnis. PT. Rineka Cipta, Jakarta, 2014.

[14]Saputra, Peran Sektor Pariwisata dalam Perekonomian Provinsi Daerah Istimewa Yogyakarta. ETD UGM, Yogyakarta, 2014. 